\title{
Smart Irigasi Berbasis Arduino Sebagai Kontrol Air Subak untuk Mempertahankan Ketahanan Pangan
}

\author{
I Kadek Agus Wahyu Raharja, Fachri Zamzami, I Gede Feryanda Fransiska, \\ I Gusti Ngurah Janardana \\ Jurusan Teknik Elektro, Fakultas Teknik, Universitas Udayana \\ *Korespondensi Email: janardana@ee.unud.ac.id
}

\begin{abstract}
Abstrak
Sistem pengairan sawah di Bali umumnya menggunakan sistem Subak. Sistem pengairan ini diatur oleh seorang pemuka adat yang juga adalah seorang petani di Bali. Pembagian air dilakukan secara merata sesuai luas lahan yang dimiliki oleh petani. Masalah yang dapat terjadi pada sistem pengairan ini seperti masyarakat yang membuka pintu air ke sawahnya tidak sesuai dengan waktu yang di sediakan oleh pemuka adat, hal ini dapat menyebabkan permasalahan yang dapat memecah persatuan di daerah tersebut. Selain itu, saat musim kemarau pembagian air terkadang tidak merata karena ketersediaan air dalam bendungan tidak memenuhi kebutuhan. Sehingga dirancanglah Smart Irigasi Berbasis Arduino bertenaga surya sebagai salah satu alat untuk mempermudah memanajemen pembagian air subak. Pemodelan yang dibuat adalah dengan mensimulasikan 3 buah petak sawah yang dialiri air dengan sumber utama adalah sungai dan sumber cadangannya berupa waduk. Sistem ini dikontrol berdasarkan waktu yang terprogram pada modul RTC dan sistem monitoring menggunakan modul GSM SIM900. Data yang didapat adalah nilai debit air pada musim hujan sebesar 2,090 L/s, musim kemarau sebesar $11,18 \mathrm{~L} / \mathrm{s}$, dan $0 \mathrm{~L} / \mathrm{s}$ pada musim kering.
\end{abstract}

Kata kunci: Irigasi, Subak, RTC, GSM SIM900

\begin{abstract}
Agriculture in Bali generally using Subak system as an irrigation system. This irrigation system is regulated by a traditional leader who is also a farmer in Bali. Water distribution is carried out according to the area of farmers land. The problems that can be happened on this irrigation system, such as the community that opens the floodgates to the rice fields, are not in accordance with the time provided by traditional leaders, and that can break the unity in the area. In addition, during the dry season the distribution of water is sometimes uneven because the availability of water in the dam does not meet the needs. So that Arduino-based Solar Powered Smart Irrigation is designed as one of the tools to facilitate the management of subak water distribution. The modeling made is to simulate 3 pieces of rice fields that are drained by water with the main source being the river and the source of the reserve in the form of a reservoir. This system is controlled based on the programmed time on the RTC module and the monitoring system uses the GSM SIM900 module. The data obtained is the value of water discharge in the rainy season of $2.090 \mathrm{~L} / \mathrm{s}$, the dry season of $11.18 \mathrm{~L} / \mathrm{s}$, and $0 \mathrm{~L} / \mathrm{s}$ in the hard dry season.
\end{abstract}

Keywords : Irrigation, Subak, RTC, GSM SIM900A

\section{PENDAHULUAN}

Pertanian di Bali merupakan salah satu sektor penyumbang pendapatan setelah sektor pariwisata, umumnya pertanian di Bali dalam sistem pengairannya menggunakan sistem subak. Subak merupakan sebuah pandangan

hidup yang sudah diterapkan oleh masyarakat Bali dan merupakan gambaran langsung dari pelaksanaan Tri Hita Karana. Subak memiliki arti penting dalam pengairan sawah di bali, yakni sebagai organisasi pengairan 
tradisional yang mengkoordinasi sistem pengairan sawah dalam proses penanaman sampai proses panen padi di Bali [1].

Sistem pengairan Subak diketuai oleh ketua adat yang biasa disebut dengan Pekaseh atau Penglimaan. Pembagian air dilakukan secara merata sesuai luas lahan yang dimiliki oleh petani. Pem-bagian air ini menggunakan pintu air yang dibuat menggunakan beton atau juga kayu, pemuka adat harus membagi air secara manual membuka dan menutup pintu air dari pintu utama bendungan ke parit kecil yang sudah terhubung ke sawah petani yang bergabung dalam subak, setelah itu petani akan membuka pintu air dari parit kecil ke sawahnya masing-masing.

Dengan sistem yang seperti ini dapat meningkatkan suatu kerja sama dalam aspek organisasi kemasyarakatan tetapi pembagian air manual juga menyebabkan pembagian air tidak merata dan juga sering terjadinya permasalahan dalam masyarakat yang membuka pintu air ke sawahnya tidak sesuai dengan waktu yang di sediakan oleh pemuka adat hal ini dapat menyebabkan permasalahan yang dapat memecah persatuan di daerah tersebut.

Pada saat musim kemarau pembagian air terkadang tidak dapat merata karena ketersediaan air dalam bendungan yang tidak memenuhi untuk mengairi sawah dan juga masyarakat membutuhkan waktu lebih banyak dalam mengatur air agar sawahnya tidak kekurangan air.

Sebagai jalan keluar dari permasalahan ini kami membuat Smart Irigasi Berbasis Arduino bertenaga surya untuk mempermudah memanajemen pembagian air subak. Sehingga, petani yang memerlukan air untuk pengairan sawahnya tidak perlu melakukan pengerjaan irigasi secara manual dan menunggu seluruh areal sawahnya teraliri, serta dapat mem- permudah pekerjaan pemuka adat dalam mengawasi pengerjaannya. Selain itu, saat musim kemarau ketersediaan air dapat dipantau dan terbagi merata melalui pintu kanal bendungan.

\section{KAJIAN PUSTAKA}

\subsection{Subak}

Subak merupakan organisasi masyarakat yang ada di Bali, dimana organisasi masyrakat ini memiliki kegunaan mengatur manajemen air atau irigasi sawah. Organisasi Subak merupakan manifestasi dari filosofi /konsep Tri Hita Karana.

Kata "Subak" merupakan bahasa Bali yang tertera pada Prasati Pandak Bandung yang dibuat pada tahun 1072 M. Subak merupakan suatu organisasi keagamaan dan sosial yang memiliki sistem norma atau pengaturan sendiri, sistem musyawarah dari para petani dalam menentukan tata cara penggunaan air irigasi dalam proses penanaman sampai proses panen padi.

Subak merupakan sebuah pandangan hidup yang sudah di-terapkan oleh masyarakat Bali dan merupakan gambaran langsung dari pelaksanaan Tri Hita Karana.

Pembagian air pada sistem Subak dilakukan dengan sangat adil dan merata, dan beberapa hal seperti penetapan waktu tanam, jenis padi yang ditanam dan lainnya, juga dibahas dalam musyawarah dalam Subak [1].

\subsection{Arduino Mega}

Arduino adalah modul hardware yang telah terkombinasi dengan software berbasis mikrokontroler sebagai media pengembangan elektronika yang mudah digunakan. Arduino Mega adalah papan pengem- 
bangan (development board) mikrokontroler yang berbasis chip ATmega2560. Arduino Mega memiliki pin input dan output sebanyak 54 buah pin digital, 16 buah pin analog, dan 4 pin serial port hardware. Dengan kelengkapan yang disediakan oleh Arduino Mega ini, dapat mempermudah dalam pembuatan alat, dan Arduino Mega digunakan sebagai pusat pengendalian dari Smart Irigasi Berbasis Arduino. Pemrograman Arduino Mega dapat dilakukan dengan meng-gunakan Arduino Software (IDE) [2]. Arduino Mega yang digunakan dapat dilihat pada Gambar 1.

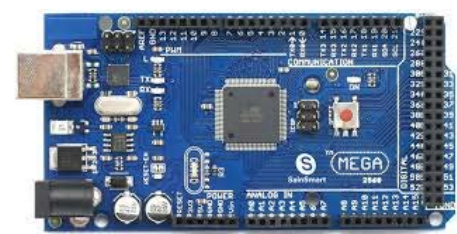

Gambar 1. Arduino Mega

\subsection{Global System for Mobile Communication (GSM)}

Global System for Mobile

Communication (GSM) merupakan teknologi selular berbasis digital. GSM bekerja dengan menggunakan gelombang mikro dengan pembagian waktu dalam mengirimkan sinyal. GSM merupakan sistem telekomunikasi yang paling banyak dipakai dan juga sudah menjadi standar telekomunikasi secara global [3].

GSM yang digunakan untuk Smart Irigasi Berbasis Arduino adalah Modul GSM SIM900 Shield. Modul ini yang merupakan modul GSM yang dirancang oleh Iteadstudio dan dapat dikontrol mengunakan AT Command. Modul GSM yang digunakan dapat dilihat pada Gambar 2.

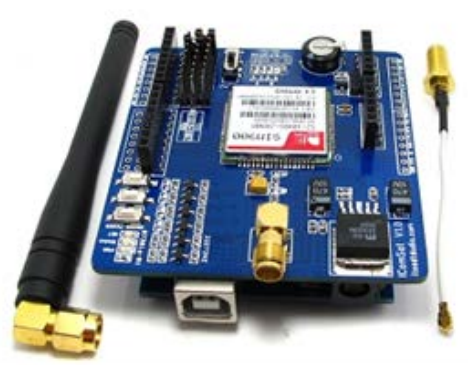

Gambar 2 Modul GSM SIM900

\subsection{Panel Surya}

Panel Surya atau modul surya merupakan alat atau modul yang terdiri dari beberapa segment surya untuk menghasilkan energi listrik dari cahaya matahari. Karena dalam pengaplikasian Smart Irigasi Berbasis Arduino memerlukan tegangan dengan arus direct current (DC), maka output dari panel surya akan digunakan untuk mengecas baterai, lalu tegangan baterai yang digunakan untuk mensupply tegangan untuk Smart Irigasi Berbasis Arduino. Alasan digunakannya panel surya adalah memanfaatkan energi matahari sebagai energi terbaharukan sehingga dapat memperkecil biaya dalam pengaplikasiannya dan pengguna hanya merawat atau memantau kerja dari panel surya tersebut.

Efisiensi kerja Panel surya yang maksimal adalah dengan posisi panel surya menghadap langsung ke sinar matahari. Pada panel surya yang baik memiliki pelindung overheating yang bertujuan untuk menjaga efisiensi kerja dari Panel Surya, dimana panel surya hanya dapat mengkonversi kurang dari $20 \%$ dari energi matahari yang didapat [4]. 


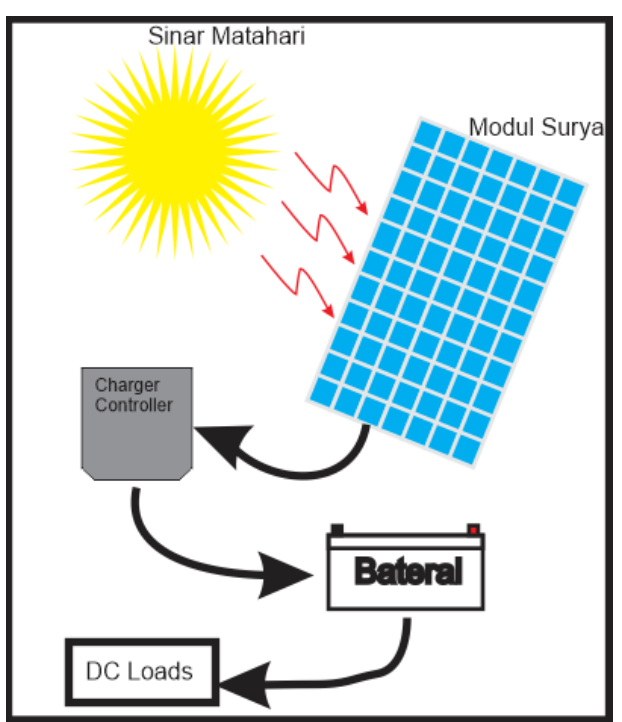

Gambar 3. Proses penggunaan Panel Surya

\subsection{Selenoid Valve}

Selenoid Valve adalah katup buka tutup yang dapat dikontrol menggunakan inputan arus AC/DC yang masuk ke dalam kumparan pada katup. Solenoid Valve biasa digunakan pada sistem kontrol pada sistem fluida. Pada sistem pneumatik, solenoid valve berfungsi sebagai pengatur keluar masuk udara menuju aktuator atau silinder pada penampung air sehingga tandon tempat penampungan itu tidak kosong.

Selenoid Valve terdiri dari dua jenis berdasarkan cara kerja, yaitu Normally Close dan Normally Open. Pada Selenoid Valve memiliki lubang inlet yang berfungsi untuk tempat masuknya fluida, lubang outlet yang berfungsi sebagai tempat keluar fluida, dan exhaust sebagai pembuangan fluida yang terjebak.



Gambar 4. Prinsip Kerja Selenoid Valve

Selenoid Valve akan berfungsi saat kumparan mendapatkan catu da yang sesuai dengan tegangan kerja, biasanya pada tegangan DC akan digunakan tegangan 12/24 Volt DC. Setelah mendapatkan tegangan maka akan timbul gaya magnet yang menarik sebuah pin, sehingga akan menyebabkan fluida mengalir dari $C$ ke $D$. Hal ini akan menyebabkan tekanan di $\mathrm{C}$ turun sehingga katup utama terbuka dan mengalirkan fluida dari A ke $F$ [5].

\subsection{Real Time Clock (RTC) DS1307}

RTC DS1307 merupakan IC yang berfungsi untuk menyimpan dan memberi informasi data waktu digital. Pada sistem Smart Irigasi berbasis Arduino modul RTC akan digunakan sebagai komponen pengecekan waktu pada sistem untuk Pekaseh atau user.

Modul RTC memberikan informasi dari mulai detik sampai jam, serta hari, tanggal, bulan, dan tahun. Pada modul RTC yang digunakan dapat mengetahui catu daya yang digunakan. Apabila sumber pada sistem mati maka modul RTC akan secara otomatis mengambil sumber tegangan ke baterai yang telah terpasang pada modul.

\section{METODE PERANCANGAN}

Penelitian alat ini dilakukan di Student Center Universitas Udayana 
dan Subak Abian Tunas Mekar Taman Sari, Desa Bantang, Kec. Kintamani, Kab. Bangli. Penelitian ini dimulai pada bulan Mei 2018 sampai Juli 2018. Alur dari penelitian ini dilakukan dengan beberapa tahapan yang ditunjukan pada Gambar 5 dan 6.

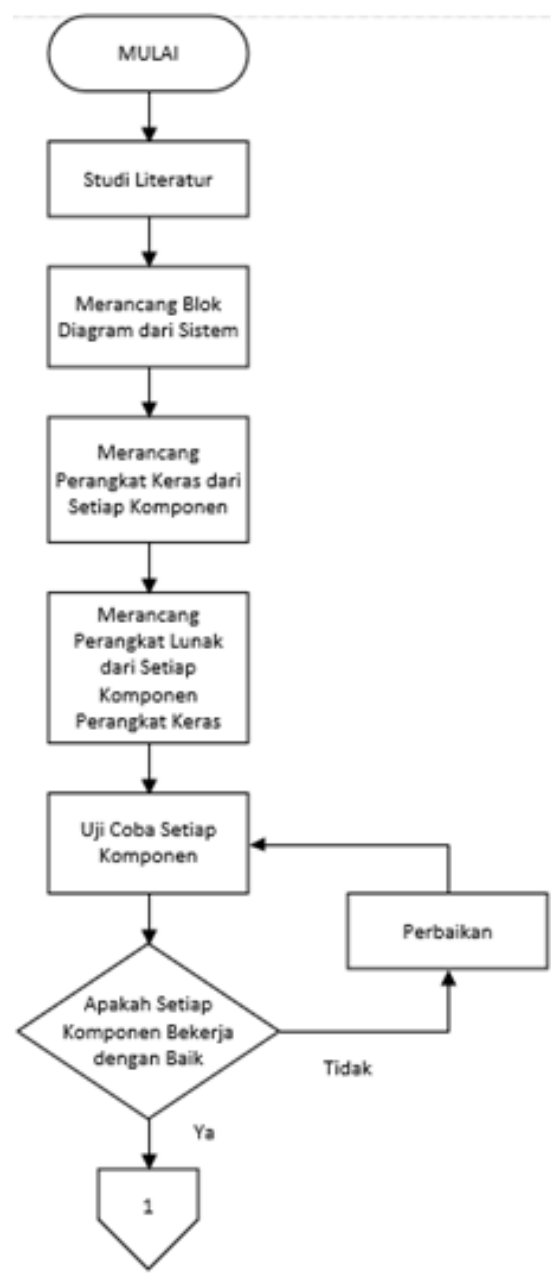

Gambar 5. Diagram Alir Penelitian

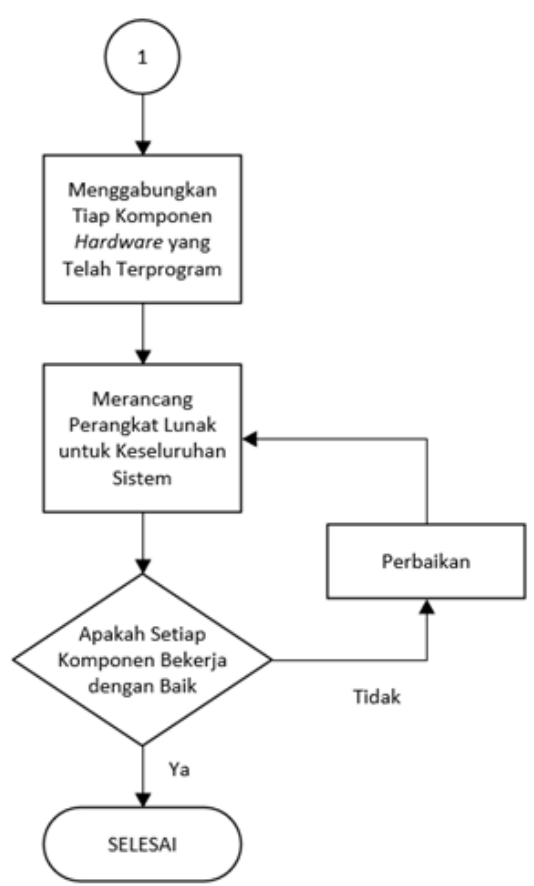

Gambar 6. Diagram Alir Penelitian

\subsection{Perancangan Hardware dan Software}

Perancangan Hardware akan dibuat menggunakan aplikasi SketchUp yang ditunjukan pada Gambar 7, 8, dan 9.

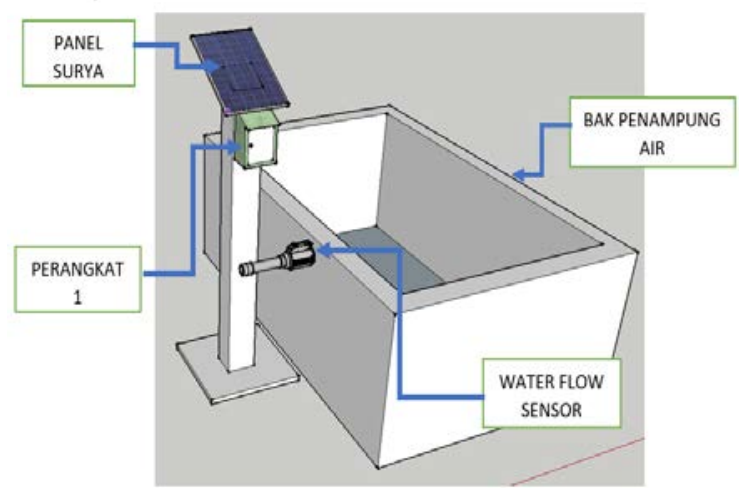

Gambar 7. Desain Bak Penampungan 


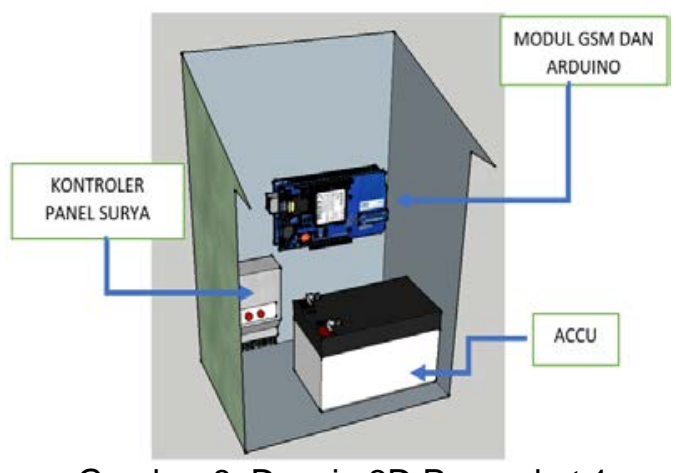

Gambar 8. Desain 3D Perangkat 1

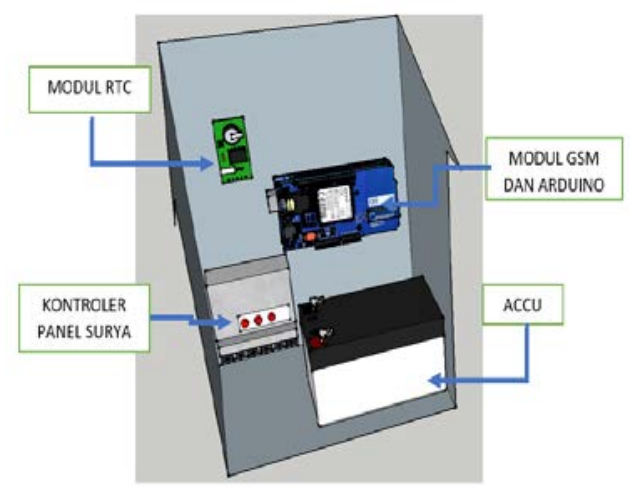

Gambar 9. Desain 3D Perangkat 2

Berdasarkan Gambar 7, 8, dan 9 dapat dilihat pemodelan dari perangkat sistem yang akan dibangun. Pada Gambar 7 merupakan pemodelan waduk tempat menampung air yang nantinya akan mengalir ketiap - tiap sawah. Sementara Gambar 8 dan 9 merupakan pemodelan dari Perangkat kontrol dimana komponen utamanya ialah Arduino mega dan modul GSM SIM900.

Sementara untuk software yang dibangun akan mengunakan aplikasi Arduino IDE. Diagram blok dari tiap perangkat dapat dilihat pada Gambar 10.

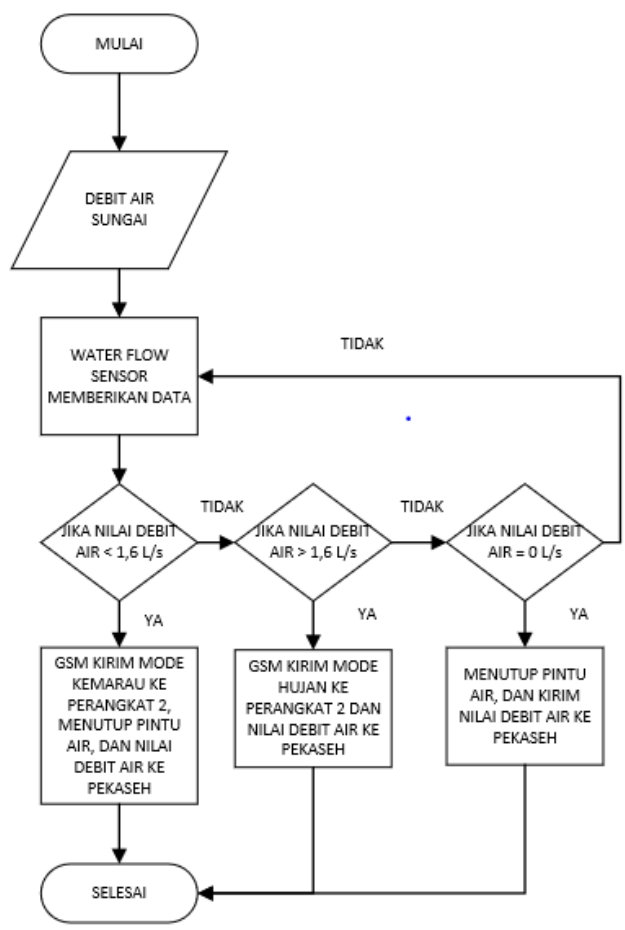

Gambar 10. Diagram Alir Perangkat 1 Berdasarkan diagram alir pada perangkat 1 dapat dilihat sistem kerjanya adalah menggunakan inputan berupa nilai debit air yang melalui water flow sensor. Apabila water flow sensor memberikan data debit air kurang dari 1,6 L/s maka perangkat 1 akan mengirim SMS berupa nilai debit air pada pemuka adat atau Pekaseh serta mengirim SMS mode kemarau pada Perangkat 2. Sementara apabila debit air mencapai lebih dari $1.6 \mathrm{~L} / \mathrm{s}$ maka perangkat 1 akan mengirim mode hujan pada perangkat 2 serta pada Pekaseh, serta menutup pintu air menuju tiap-tiap sawah petani untuk menjaga ketersedian air yang tertampung pada bak penampungan air. Sementara saat nilai water flow sensor sebesar $0 \mathrm{~L} / \mathrm{s}$ maka pintu air tertutup dan perangkat mengirim notifikasi SMS ke Pekaseh. Sistem kerja dari Perangkat 2 dapat dilihat pada Gambar 11. 


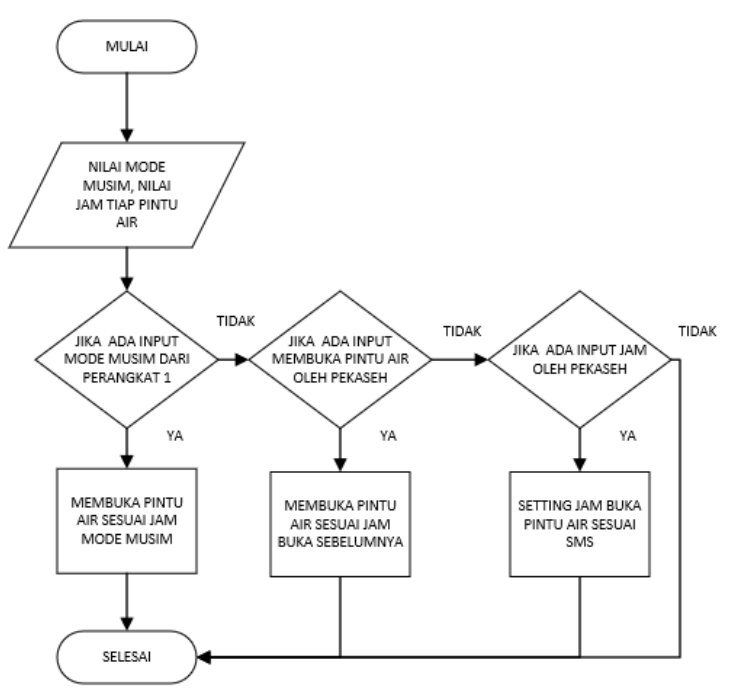

Gambar 11. Diagram Alir Perangkat 2

Berdasarkan diagram alir pada perangkat 2 dapat dilihat sistem kerjanya adalah menggunakan inputan berupa nilai jam tiap saluran air yang menuju langsung pada sawah para petani. Nilai jam ini akan diberikan oleh Pekaseh melalui SMS. Selain itu, Perangkat 2 juga menggunakan inputan mode musim yang diterima dari SMS pada Perangkat 1.

\subsection{Metode Pengerjaan dan Uji Coba}

Metode pengerjaan dan uji coba yang dilakukan adalah :

1. Melakukan pemasangan panel surya, control charger dan accu sebagai sumber tegangan.

2. Merangkai controller yaitu arduino, sensor water level, sensor pendukung dan komponen lainnya yaitu, resistor, kapasitor, LED, dan transistor.

3. Menghubungkan mekanik pintu kanal air dengan controler dan power supply.

4. Sementara untuk uji coba akan dilakukan dengan membandingkan data di lapangan dengan prototipe yang dirancang.

\section{HASIL DAN PEMBAHASAN}

\subsection{Pengujian Power Supplay}

Power Supplay yang digunakan tiap perangkat adalah 14 volt DC yang bersumber dari accu yang terpassang pada tiap perangkat. Untuk rangkaian tiap perangkat akan menggunakan sumber tegangan sebesar 5 volt sehingga diperlukan modul step down. Disini digunakan modul LM2596 sebanyak dua buah, masing-masing untuk mensuplai mikrokontroler dan modul GSM SIM900A. Pengujian yang dilakukan untuk power suplai adalah dengan mengukur langsung keluaran dari modul step down yang digunakan. Gambar pengujian dapat dilihat pada Gambar 12.

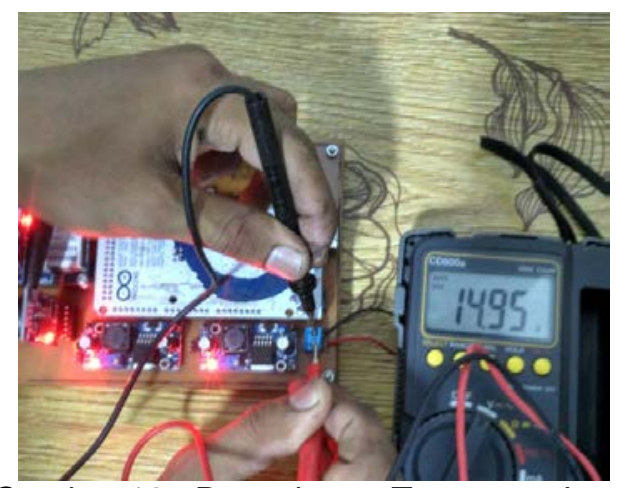

Gambar 12. Pengukuran Tegangan Input Dari Charger Kontroler

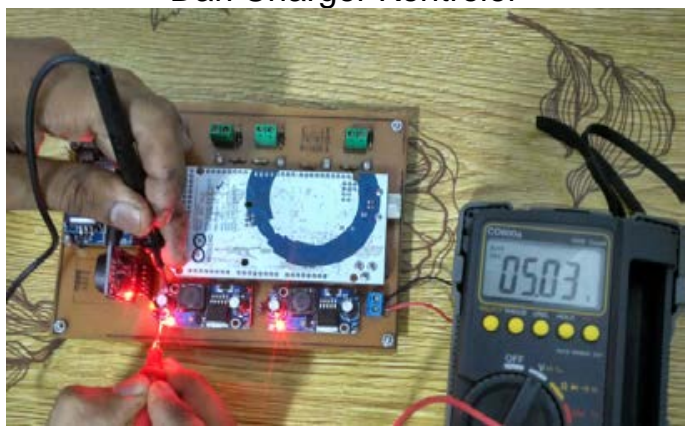

Gambar 13. Pengukuran Tegangan Input Rangkaian

\subsection{Pengujian Charger Controller}

Modul charger controller yang digunakan memiliki kriteria tegangan input $12 \mathrm{~V} / 24 \mathrm{~V}$ dengan arus maksimum 20A. pengujian yang dilakukan adalah dengan melihat waktu modul untuk mengisi kembali daya pada accu. 
Pada pemasangan pertama level accu bernilai satu bar dari tiga bar yang bias diukur oleh modul charger controller. Dan waktu yang dibutuhkan untuk mengisi sampai terukur mencapai dua bar adalah selama 1 hari penuh. Berikut gambaran level dari accu pada charger controller.

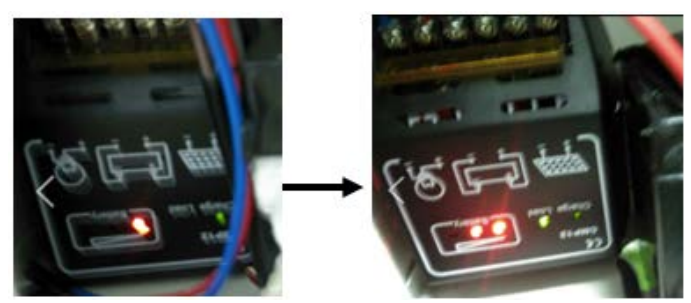

Gambar 14. Level Accu

\subsection{Pengujian Water Flow Sensor}

Water flow sensor memberikan nilai sesuai pemodelan yang dibuat. Dimana, nilai untuk musim kemarau adalah dibawah $0,6 \mathrm{~L} / \mathrm{s}$, nilai untuk mode penghujan adalah diatas $0,6 \mathrm{~L} / \mathrm{s}$, dan nilai dari mode kering adalah $0 \mathrm{~L} / \mathrm{s}$. Berikut adalah gambaran pengujian yang dilakukan dimana apabila system telah mencapai mode kemarau maka valve digital yang terpasang pada saluran keluar air dari bak penampungan akan menutup. Hasil dari pengujian dapat dilihat pada Gambar 15 dan 16.

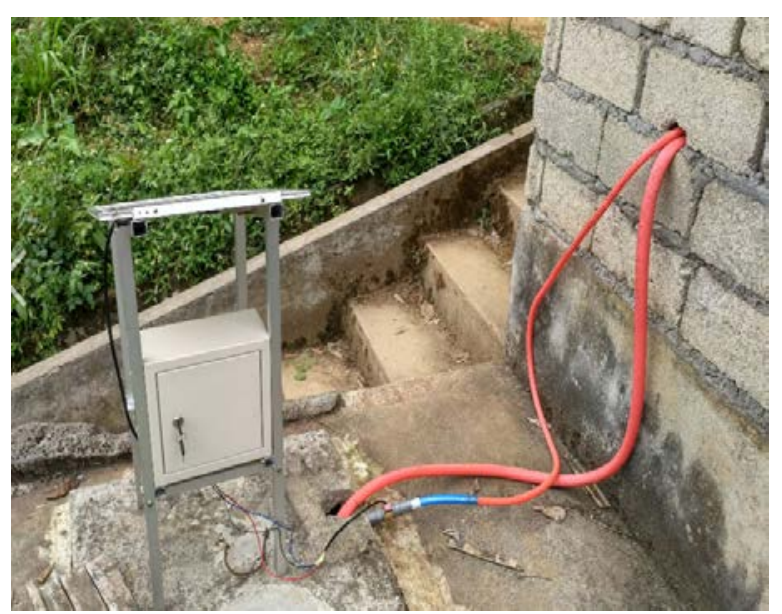

Gambar 15. Penempatan Perangkat untuk Pengujian Secara Langsung

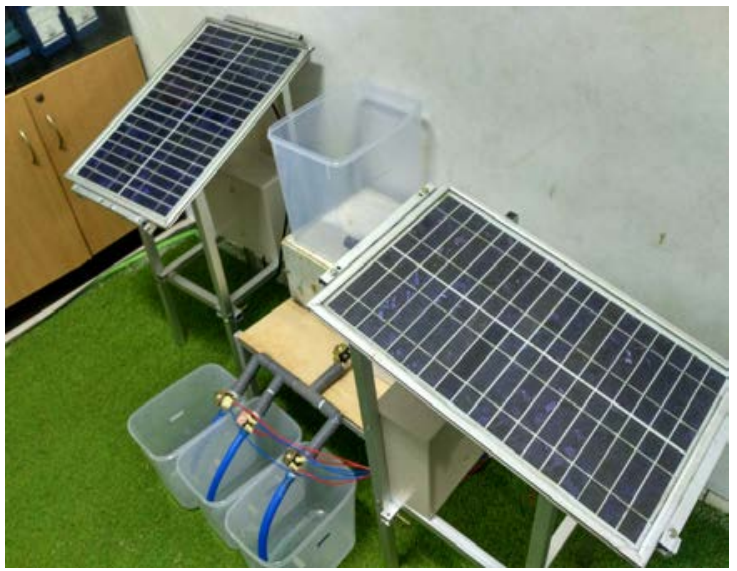

Gambar 16. Penempatan Perangkat Untuk Pengujian dengan Model Petak Sawah

Berdasarkan proses pengujian yang dilakukan maka dapat dilihat perbandingan nilai debit air yang terukur oleh water flow sensor pada model yang dibuat dengan sumber air secara langsung dapat dilihat pada Tabel 1.

Tabel 1. Perbandingan Debit Air

\begin{tabular}{|l|l|l|}
\hline Musim & $\begin{array}{l}\text { Secara } \\
\text { Langsung }\end{array}$ & $\begin{array}{l}\text { Dengan } \\
\text { Model }\end{array}$ \\
\hline Hujan & $24,54 \mathrm{~L} / \mathrm{s}$ & $2.090 \mathrm{~L} / \mathrm{s}$ \\
\hline Kemarau & $11.18 \mathrm{~L} / \mathrm{s}$ & $1,636 \mathrm{~L} / \mathrm{s}$ \\
\hline Kering & $0,000 \mathrm{~L} / \mathrm{s}$ & $0,000 \mathrm{~L} / \mathrm{s}$ \\
\hline
\end{tabular}

Berdasarkan Tabel 1 maka dapat dilihat perbandingan model prototipe dari sumber air yang dibuat dengan sumber air pada tempat aslinya memiliki perbandingan $1: 12$.

\subsection{Pengujian Sistem}

Pada Pengujian Perangkat 1 akan dilihat reaksi perangkat saat nilai data flow sensor berubah mode. Akan dilihat SMS yang dikirim oleh perangkat menuju Pengguna dan menuju $\mathrm{Pe}$ rangkat 2 dan dilihat bagaimana respon dari Perangkat 2 yang pemo-delannya ditunjukan pada Gambar 8. Hasil dari pengujian dapat dilihat pada Tabel 2 
Tabel 2. Perbandingan Respon Perangkat 1 dan Perangkat 2 terhadap Debit Air yang Masuk

\begin{tabular}{|c|c|c|}
\hline $\begin{array}{l}\text { Nilai Debit } \\
\text { Air }\end{array}$ & Perangkat 1 & Perangkat 2 \\
\hline $2.090 \mathrm{~L} / \mathrm{s}$ & $\begin{array}{l}\text { SMS mode } \\
\text { hujan pada } \\
\text { Perangkat } 2 \\
\text { dan } \\
\text { Pekaseh }\end{array}$ & \begin{tabular}{l}
\multicolumn{2}{l}{ Membuka } \\
pintu air \\
pada petak \\
sawah \\
sesuai jam \\
musim hujan
\end{tabular} \\
\hline $1,636 \mathrm{~L} / \mathrm{s}$ & $\begin{array}{l}\text { Menutup } \\
\text { pintu air, } \\
\text { SMS mode } \\
\text { kemarau } \\
\text { pada } \\
\text { Perangkat 2, } \\
\text { dan } \\
\text { Pekaseh }\end{array}$ & \begin{tabular}{l}
\multicolumn{2}{l}{ Membuka } \\
pintu air \\
pada petak \\
sawah \\
sesuai jam \\
musim \\
kemarau
\end{tabular} \\
\hline $0,000 \mathrm{~L} / \mathrm{s}$ & $\begin{array}{l}\text { Menutup } \\
\text { pintu air, } \\
\text { SMS mode } \\
\text { kering pada } \\
\text { Perangkat 2, } \\
\text { dan } \\
\text { Pekaseh }\end{array}$ & \begin{tabular}{l}
\multicolumn{2}{l}{ Membuka } \\
pintu air \\
pada petak \\
sawah \\
sesuai jam \\
musim \\
kemarau
\end{tabular} \\
\hline
\end{tabular}

\section{KESIMPULAN}

Berdasarkan penelitian yang telah dilakukan maka dapat diberikan kesimpulan sebagai berikut :

1. Smart Irigasi Berbasis Arduino Sebagai Kontrol Air Subak menggunakan solar panel atau modul surya untuk mengubah energi matahari menjadi listrik yang disimpan pada baterai yang selanjutnya nilai tegangan dari baterai akan dikonversi menyesuaikan dengan rangkaian mikrokontroler.

2. Sistem Smart Irigasi Berbasis Arduino bertenaga surya sebagai suatu alat yang dapat mempermudah memanajemen pembagian air subak untuk meningkatkan produktifitas petani di Bali, dimana alat bekerja berdasarkan waktu yang telah diatur oleh Pekaseh.
3. Sistem Smart Irigasi Berbasis Arduino dapat dioperasikan dengan sangat fleksibel, dimana dengan menggunakan pengaturan berdasarkan waktu yang diinputkan oleh Pekaseh. Sehingga sistem ini tidak akan menghilangkan sistem yang terbentuk pada Subak atau menghilangkan kebudayaan yang terdapat pada daerah pemasangan.

\section{DAFTAR PUSTAKA}

[1] 2017. The BaliGlory Website. Available:

http://www.id.baliglory.com/2016/04/s ubak-bali.html. Diakses pada tanggal 22 Mei 2017.

[2] Andrianto H, Darmawan A. Belajar Cepat \& Pemrograman Arduino. Bandung: Informatika. 2016.

[3] 2011. ITead Studio. "Datasheet IComsat v1.1-SIM900 GSM/GPRS Shield".

http://imall.iteadstudio.com/im120417 009.html. Diakses tanggal 21 Mei 2017.

[4] Siahaan A, Implementasi Panel Surya Yang Diterapkan Pada Daerah Terpencil Di Rumah Tinggal Di Desa Sibuntuon Kecamatan Habinsaran, Repositori Tugas Akhir Mahasiswa HUMRAH. 2016.

[5] 2015. The Wikipedia Website. Available:

https://en.wikipedia.org/wiki/Solenoid valve. Diakses pada tanggal 22 Mei 2017.

[6] Suardiana N. Rancang Bangun Sistem Pembacaan Jumlah Konsumsi Air Pelanggan PDAM Berbasis Mikrokontroler Atmega328 Dilengkapi SMS. Research Gate. 2016.

[7] 2015. Teori Motor DC Dan JenisJenis Motor DC. http://elektronikadasar.web.id. Diakses pada tanggal 22 Mei 2017

[8] 2013. Pengertian dan Fungsi Baterai Aki

http://www.kitapunya.net/2013/12/peng ertian-dan-fungsi-baterai-aki.html. Diakses pada tanggal 16 Mei 2017 